\title{
What explains neighborhood type statistically? Mixing typo-morphological and spatial analytic approaches in urban morphology
}

\author{
Todor Stojanovski \\ Urban and Regional Studies. KTH Royal Institute of Technology. Stockholm, Sweden \\ E-mail: todor.stojanovski@abe.kth.se
}

\begin{abstract}
Society creates architectural styles and neighborhood types to communicate and promote values. Accordingly, geographers and architects working within the typo-morphological tradition classify neighborhoods by historical periods, urban design, planning paradigms and plan elements, building types and architectural detail. This paper juxtaposes typo-morphological (historical emergence of urban forms through urban elements and pattern typologies) and spatial analytic (city defined by urban form factors and formulas) approaches in urban morphology to assess what explains neighborhood type statistically. The analyses of variance show that many urban form factors (residential and employment density, Floor Space Indexes (FSI), location, income, etc.) are statistically significant in neighborhood type (as a nominal composite variable). Neighborhood typologies can be applied to enrich spatial analyses and urban modelling. The approach can be used in typo-morphological tradition to offer quantitative description to the persistent 'problem of type' and enrich the classification methodology.
\end{abstract}

Keywords: urban morphology, neighborhood, typology, typomorphology, spatial analysis, urban variables

\section{Introduction}

Cities are diverse and complex and there are many ways to describe and understand them (Kropf, 2009). Typo-morphological tradition in urban morphology (see historicogeographical and typo-processual approaches in Kropf, 2009; see Conzen, 1960; Whitehand, 2001; Cataldi et al. 2002; Cataldi, 2003) looks at historical emergence of urban forms and typological consistencies (variations of generic urban patterns). The methodology is to identify and dissect various urban elements (Moudon, 1997, p.3; see Conzen, 1960; Lynch, $1960)$ or to recognize and abstract urban patterns (Marshall and Çalişkan, 2011, p.421; Alexander, 1979). The morphologists in the spatial analytic approach (in Kropf, 2009; see Harris, 1965; Batty, 1976; 2005) build urban models and symbolical representations of cities and their dynamics (Batty, 2016, p.242).
The city is defined quantitatively in terms of measurable factors as n-dimensional space and aggregation of $\mathrm{N}$ individuals in interaction (Chadwick, 1971).

Swedish typo-morphology has a long tradition (Abarkan, 2009; 2013). Many morphologists argue that Swedish neighborhood typology explains not only residential density, Floor Space Indices (FSI), etc. (Rådberg 1988; Rådberg \& Friberg 1996), but also social structure and development tendencies (Engström et al. 1988). The neighborhood type has a distinctive social meaning and status. The social layer of the neighborhood type is preconditioned by the physical form of its emergence and subsequent planning measurements, but defined by general societal and economic development. Trends like globalization, transnational capitalism and network society, change from welfare to knowledge economics, etc. 
redefine the meaning and social status, and subsequently population and social structure in neighborhood types (Engström, 2008). This paper studies the city of Karlstad by combining typo-morphological methodology and statistical analytics. The analysis shows that many urban form factors (residential and employment density, mix of residences and jobs, Floor Space Indexes (FSI), location, income, etc.) are statistically significant in neighborhood type (as a nominal composite variable). The neighborhood typology can be applied to cluster urban form variables or in urban modelling to discuss urban futures from a perspective of typological processes or process typologies (Kropf, 2001). The approach can be used in typo-morphological tradition to offer quantitative description to the persistent 'problem of type' and enrich the classification methodology.

The following section outlines the problem formulation and research hypothesis about neighborhood type. The methodology is described in section 2. Section 3 and 4 present and discuss the typo-morphological study of Karlstad and the results of the statistical analyses of neighborhood type. The last section includes conclusions and directions for a future research.

\section{Problem formulation and research hypothesis}

Major social, economic or technological revolutions (industrialization, welfare state or neoliberalism; steel, concrete, asphalt technologies and prefabrication; railways and trains, expressways and automobilism, computers, digitization and automation, etc.) trigger development cycles, building booms which are followed by slumps (Whitehand, 1987). Neighborhoods who emerge during building booms incorporate and display similar architectural styles and plan elements, urban design coding, building and transportation technologies which are specific for that historical era. These neighborhoods become morphological consistent artefacts imbedded in the city.
Society creates architectural styles and neighborhood types in order to simplify communication and promote values (Franck 1994, p.345). Neighborhood types obtain unique social meaning and status, appealing or repulsive to different strata of the population. Individuals sometimes choose and live in their favorite neighborhood type and sometimes they are stuck in a place which does not fit their preference. The taste for housing triggers social mobility and grouping of 'housing classes' (Rex and Moore, 1969; Rex, 1971). Bourdieusien conceptualization of social class by taste helps to understand housing classes. Social classes are groups of agents who occupy similar positions in social space and who, being placed in similar conditions and subjected to similar conditionings, have every likelihood of having similar dispositions and interests and therefore of producing similar practices and adopting similar stance (Bourdieu, 1985, p.725).

Developers create typical homes and neighborhood types in specific historical periods which are appealing to individuals and households. They dictate a housing supply. Typical homes and neighborhood types have particular combinations of physical elements and patterns which produce morphological consistencies, which attract particular population strata. When an individual or household looks for a residence they dream of a particular home and neighborhood. The dream house or apartment is often shared by a group of individuals with similar taste. When the group of individuals finds their particular home and neighborhood it becomes a housing class. Housing classes in typical neighborhoods are often distinctive social groups with similar social and economic characteristics, lifestyle and behavior (Figure 1A). The lifestyle and behavior, e.g. mobility, are often supported or hindered by physical elements of urban form (parking standards, street design etc.). The research hypothesis is that neighborhood type incorporates a range of physical (urban form) variables due to morphological consistencies in historical evolution of cities and indirectly even socioeconomic and demographic variables as a consequence of social grouping and housing class formation (Figure 1B). 

A CREATION OF HOUSING CLASSES
(SOCIAL GROUPING BY TASTE FOR HOMES)
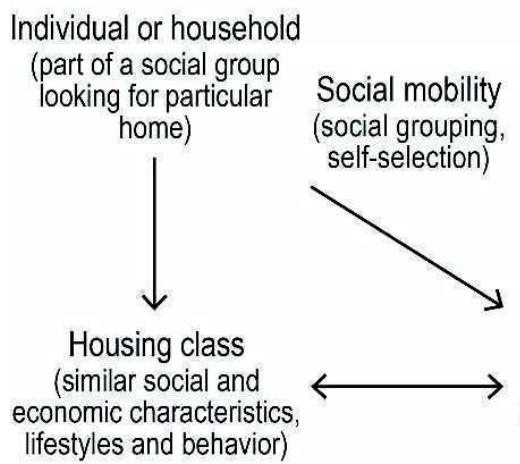

\section{Urban form (physical elements}

Social mobility self-selection)

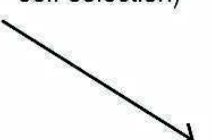
and/or patterns) (social grouping,

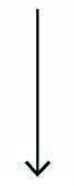

Building/ neighborhood type (particular combination of physical elements and/or patterns)

B HYPOTHESIS:

NEIGHBORHOOD TYPE DESCRIBES A RANGE OF PHYSICAL, AND INDIRECTLY SOCIOECONOMIC AND DEMOGRAPHIC FACTORS AS A CONSEQUENCE OF MORPHOLOGICAL SIMILARITIES; SOCIAL GROUPING AND HOUSING CLASS FORMATION.

Socioeconomic and demographic
variables

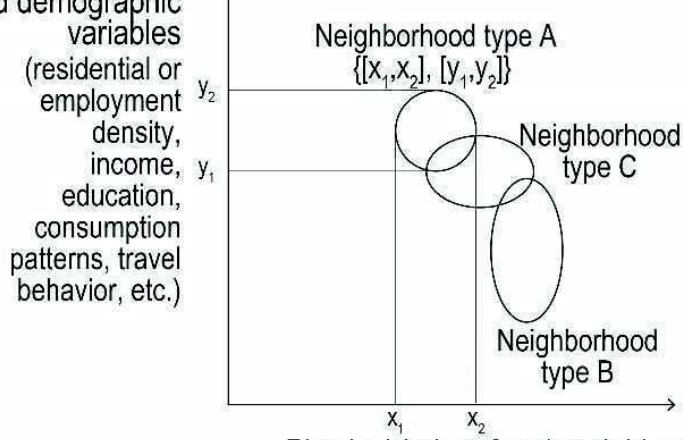

Physical (urban form) variables (location, Floor Space Index (FSI), lot and block size, street width, building height, etc.)

Figure 1.

Creation of housing classes and research hypothesis about neighborhood type

The following section describe the methodology to analyze the research hypothesis.

\section{Methodology}

The typo-morphological and spatial analytic approaches define neighborhood types differently. Methods as surveys, observations and classifications are favored in the first, whereas statistical classification which reduce dimensions as cluster or factor analysis are preferred in the second tradition. It is not common to mix qualitative typo-morphological studies and quantitative statistical analyses, even though there are morphological analyses which use descriptive statistics for example for parameters of lots and building footprints (Hall, 2008; 2010) or street patterns parameters (Southworth and Owens, 1993; Southworth and Ben-Joseph, 1997). The following two subsections describe the typo-morphological and statistical method used in the Karlstad's study.

\section{Typo-morphological method}

There no right or wrong methodology to classify neighborhood into a typology
(Marshall, 2005). There are no two identical neighborhoods in one city. There is never an ideal match between neighborhoods of one type. The creation of neighborhood typology is basically pattern matching based on exploration of the historical evolution of the city, generalizations and abstractions. Genotypes emerge and propagate in specific historical periods. The cities comprise of few hundred generic patterns in many variations (Alexander, 1979). The classification of abstract genotypes and their compilation in neighborhood typology is typically based on:

1) combinations of plan elements (streets, lots and buildings); 2) historical layering of the urban fabric; and 3) building and land utilization (Conzen, 1960; Whitehand, 2001; Birkhamshaw and Whitehand, 2012; Figure 2A). Neighborhood type is often a combination of these elements (illustrated on Figure 2B). Even though there are many possible combinations, only few of them are viable. A combination of a single house (A), a grid street layout ( $\mathrm{B}$ or $\mathrm{C}$ ) and a lot division type $\mathrm{A}$ would be non-sense in practice. Furthermore, specific combinations of elements are preferred in different historical periods. A neighborhood prototype emerges in certain historical era and if it becomes fashionable as housing solution it is replicated. These neighborhood types 
A Elements in Conzenian school of urban morphology

A1 City block elements

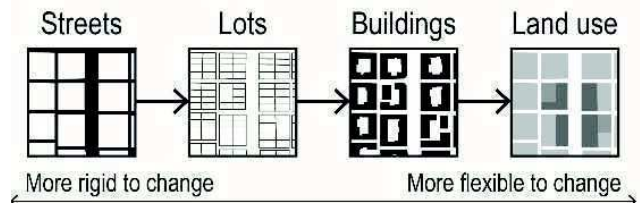

A2 City elements (historical layers/development cycles)

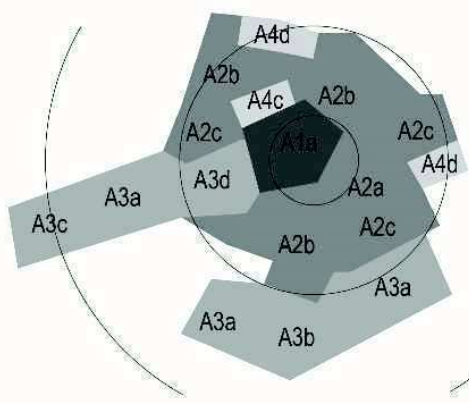

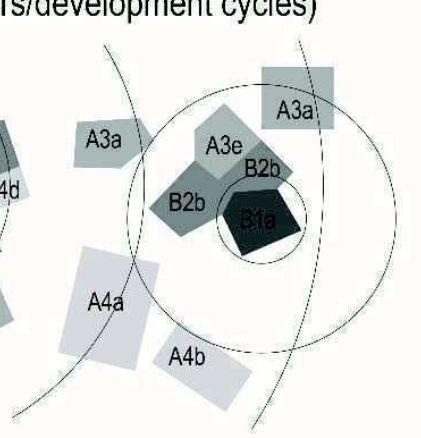

A, B... Cities/towns

1,2... Neighborhood emerging from transportation eras

- 1 Era of walking and horseback 2 Era of carriages and coaches 3 Era of public transportation 4 Era of private automobile

a, b... Neighborhood types (differentiated by distinctive patterns of streets, lots and buildings; e.g. a=AACAC, $b=C C B A D \ldots)$

B How to classify neighborhood type? (period+street layout+lot division+building type+land use)

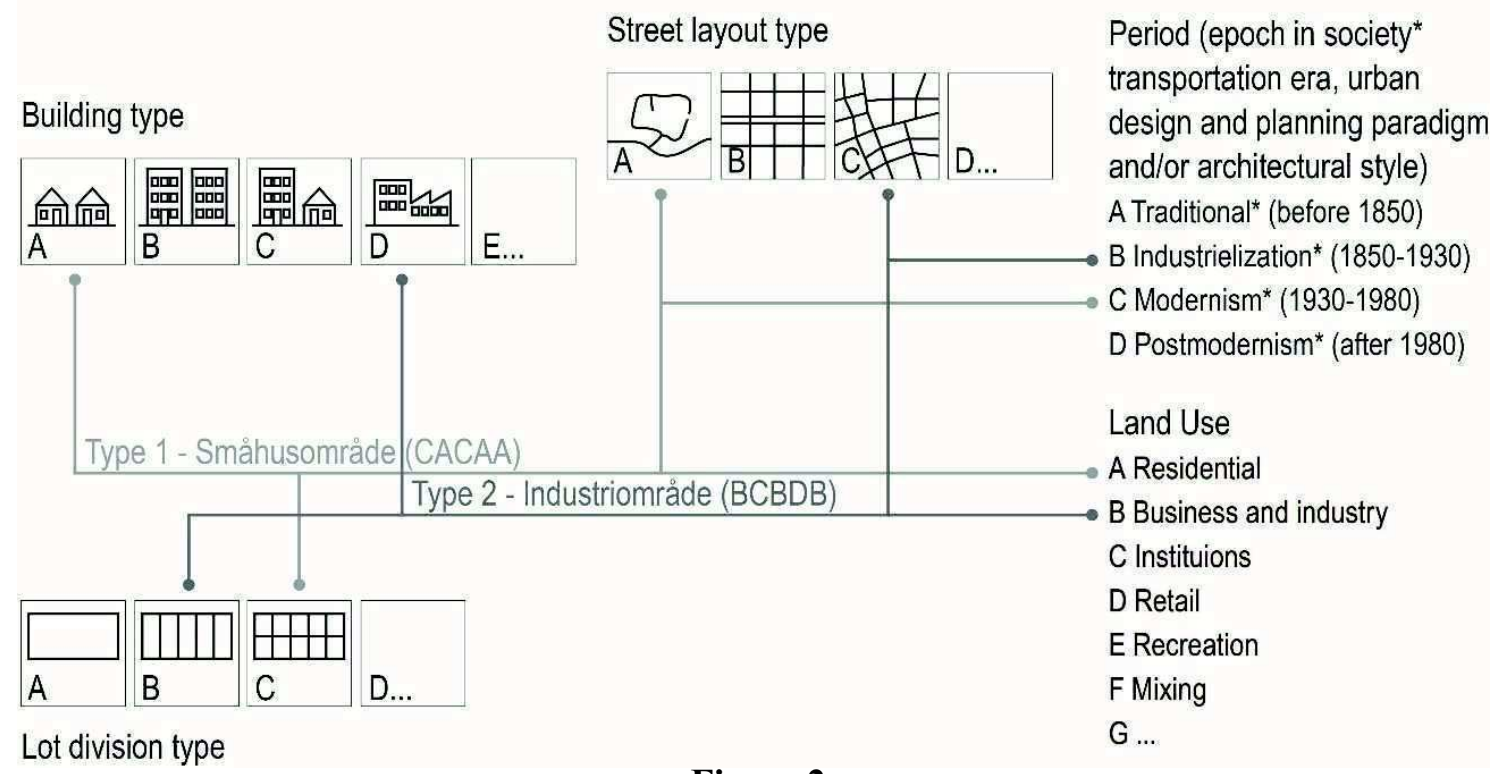

Figure 2.

Typo-morphological method (B) inspired by the Conzenian school (A)

usually have their own history and narrative supporting the morphology (see Panerai et al. (2014) about a classical typo-morphological study of Wester European cities, or Southworth and Ben-Joseph (1997) for evolution of streets in American towns and cities or the transformation of the main street to a shopping mall (Southworth, 2005)).

Swedish typo-morphology has a long tradition (Abarkan, 2009; 2013). Many municipalities (like Stockholm and Malmö) use neighborhood typologies as a background for design codes or building regulations (SBK,
1997; 2000). The report "Denser Stockholm" illustrates typological processes for typomorphological densification on city block level (SLL, 2009). Neighborhood and building typologies have been developed in Sweden by: 1) architectural styles (Björk et al., 1983; 2003; 2009); 2) design codes and planning paradigms (Rådberg, 1988; Rådberg and Friberg, 1996); and 3) the socioeconomic epochs (Engström et al., 1988). The first tradition is focused on building type, architectural detail, façade design and building materials. Rådberg's (1988) hypothesis is that neighborhood type 


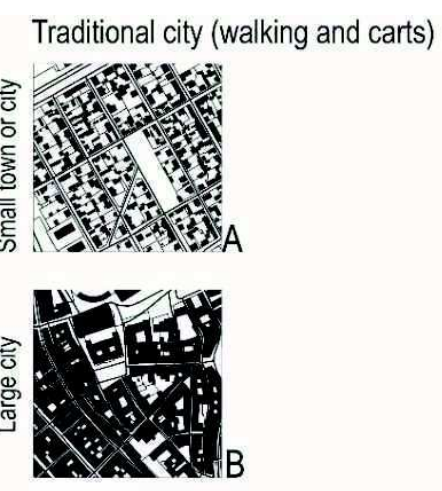

Industrial city (walking and public transportation)

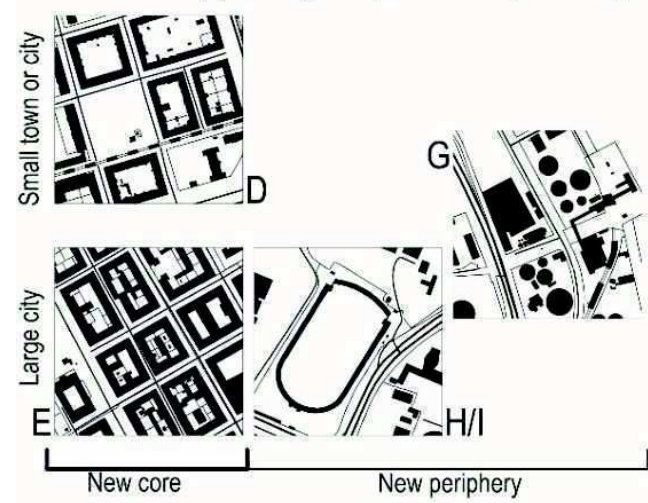

Modernist city (private automobiles)
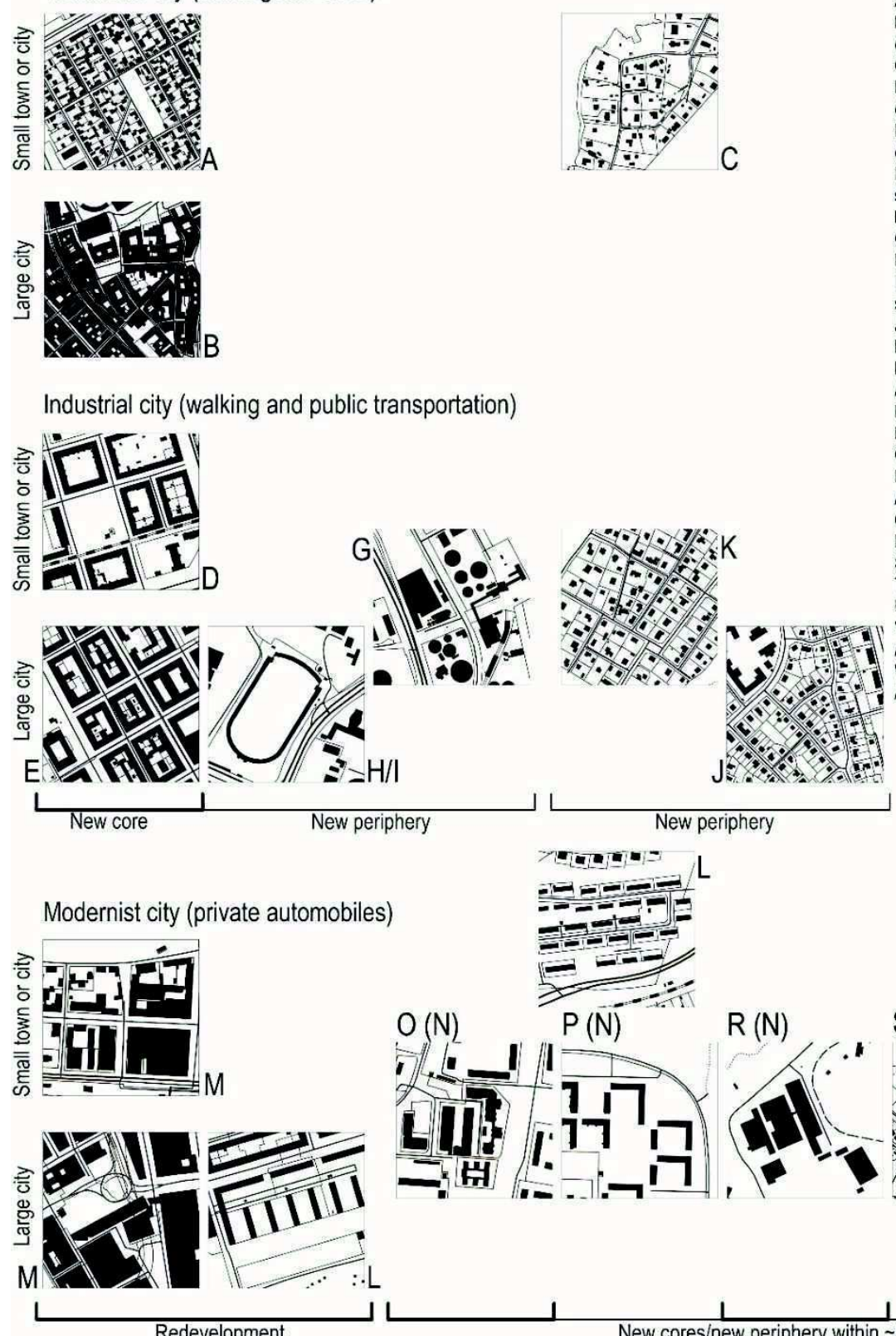

A Trästad/wooden city

B Stenstad (preindustriell)/stone city

(preindustrial)

$\mathrm{C}$ (Urban) by/villages

D Kringbyggd (sluten) smastadskvarter

(stenstad)/(small) stone city (industrialization)

E Kringbyggd (sluten) storstadkvarter

(stenstad)/(large) stone city (industrialization)

F Kringbyggd (sluten) storstads-

storgärdskvarter/(large) stone city with

large courtyards (industrialization)

$\mathrm{G}$ Industriområdelindustrial zone

$\mathrm{H}$ Institutionsomráde/institutions

I drotts-, kultur- eller rekreationsomráde

sports and recreation

J Trädgärdsstad/garden city

$K$ Villastad/city with villas

L Tidigare lamellhus- eller punkthusomrade

learly modernist suburb (apartment blocks and towers

M Stenstad (modernizerad)/stone city (modernized)

N Funktionalistisk stad/modernist city

O Centrum/community center

P Senare lamellhus- elier punkthusområde

Imodernist apartment blocks and towers

Q Kontorkomplex/office park

$\mathrm{R}$ Handelsomráde/external retail

S Smähusomráde/detached houses

T Radhus- eller kedjehusomrade/row houses

U Fritidshusomràde/summer houses

$\checkmark$ Nyare lamellhus- eller punkthusomrâde

-late modernist apartment blocks and towers

W Kvasi-storstadskvarter (stenstad)

/postmodernist quasi city blocks

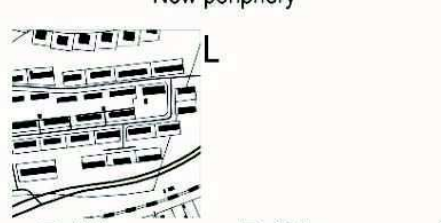

Legend

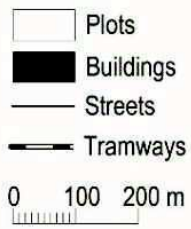

$x=$

$\begin{array}{llll}\mathrm{P}(\mathrm{N}) & \mathrm{R}(\mathrm{N}) & \mathrm{S}(\mathrm{N}) & \mathrm{T}(\mathrm{N})\end{array}$

Postmodernist city (multimodal transportation)
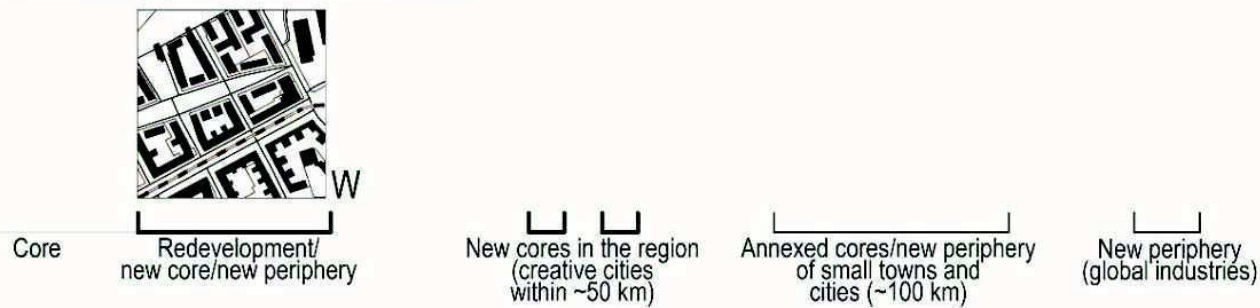

Figure 3.

Swedish neighborhood typology 
explains a range of physical factors as built density or Floor Space Indexes (FSI), lot coverage, number of stories, etc. because these variables changed systematically in Sweden with different urban design and planning paradigms. In his research he found a strong correlation between neighborhood type, place quality and housing preferences in Swedish cities (Rådberg and Johannson 1997; Rådberg, 2000). In the book "Svensk tätort" (Engstrom et al., 1988) the social aspect (population structure and development) and functional dimension was directly associated with the physical factors of built form. The following research showed systematic changes in function and social structure based on physical characteristics. Swedish town centers have long lost some activities during the welfare state redevelepments, but populated city centers and get additional activities (Engström and Legeby, 2001; Engström, 2008).

The presented Swedish neighborhood typology (Figure 3 ) is developed by combining previous typo-morphological classifications (Engström et al. 1988; Rådberg 1988; Rådberg \& Friberg 1996; SBK, 1997; 2000). The typical traditional (preindustrial) Swedish city dispays organic or rectangular street grids with wooden or stone houses organized in city blocks. The names 'trästad' ('wooden city'; Figure 3A) or 'stenstad' ('stone city'; Figure 3B) denote these neighborhood types. The medieval cities were surrounded by villages with detached houses scattered organically in the landscape (Figure $3 C)$. These villages became urbanized with the rapid motorization in the second half of the 20th century. The industrialization produced a very dense urban core, an expansion of the medieval 'stone city' (Figure 3D-E). In a same time, it created an urban fringe of industrial zones, institutional (healthcare and education) and sports complexes (Figure 3G-I). The 'trägårdstad' or 'garden city' (Figure 3J) and its residential suburban 'villastad' or 'city with villas' (Figure $3 \mathrm{~K}$ ) emerged along the first suburban railways on the end of the 19th century. The modernist movement and Nordic welfare state inspired the biggest building boom in Sweden in the mid-20th century. The experimental early modernist apartment blocks emerged on the edges of the old cores and in the suburbs from the 1930s. In the 1950s the functionalist city (Figure $3 \mathrm{~N}$ ), so called $\mathrm{ABC}$ city, mainstreamed. In $\mathrm{ABC}, \mathrm{A}$ stands for 'arbetsområde' or 'work areas' (office parks and industrial zones), B for 'bostadsområde' or 'residential areas' with apartment blocks (Figure 3P) or row houses (Figure 3T) and $\mathrm{C}$ for 'community centers' (Figure 3O). In this period parts of the old cores in the small or large cities were modernized (Figure 3M) and transformed into office parks serving an entire region. From the 1970s a new type of residential suburbs with single detached houses (Figure 3S) emerged. The urban sprawl was followed by external shopping malls (Figure $\mathrm{R})$ and new office parks. The trend in the last two decades is to develop new postmodernist neighborhoods (Figure $3 \mathrm{~W}$ ) on the industrial fringes of the old cores. In the same time the predominantly commercial old cores are refurbished to increase the number of residents.

Table 1 summarizes the characteristics of the different neighborhood types in respect to historical period, street layout, building type, dominant function and daily activity and transportation technology.

The method in the typological study includes creation of typology, surveying, recognition and matching the existing urban patterns in Karlstad with the proposed typical patterns (Figure 3). The identified typical neighborhoods were mapped in Geographic Information Systems (GIS) software (ArcGIS).

\section{Statistical method and data}

Analysis of variance (ANOVA) was conducted to examine the geocoded typical neighborhoods. ANOVA is a collection of statistical models used to analyze and compare means and the variation of means between groups (in this case neighborhood types). To assess the research hypothesis a general linear model [1] is proposed for neighborhood type as a nominal variable (SPSS uses an anchor value, intercept $\beta 0$ which equals the mean of the reference group and makes this group redundant in the model): 


$$
\mathbf{y}=\boldsymbol{\beta}_{0}+\sum_{\mathbf{n}=1}^{\mathrm{x}}\left(\boldsymbol{\beta}_{\mathrm{n}} * \mathrm{x}_{\mathrm{n}}\right)+\varepsilon
$$

x1-n nominal variables (neighborhood types $x 1-n)$ /dummy independent variable

$\beta 0$ mean (anchor in SPSS) for the urban form factor

$\beta 1-n$ parameters (deviation from the mean/ anchor) for neighborhood types (x1-n)

$$
\varepsilon \quad \text { error term }
$$

The urban form data comed from official statistics. Municipality of Karlstad and Statistiska centralbyrån (SCB, Statistics Sweden) contributed with statistical packages BILPAK, AMPAK and FASTPAK for year 2009 (at NYKO4 level). The location variables were calculated with help of GIS. Lantmäteriet's (National Land Survey of Sweden) Digital Library and municipality of Karlstad provided GIS maps and datasets. There are 6 levels and NYKO 4 in Karlstad are usually wide between $200 \mathrm{~m}$ (two by two city blocks in the old urban cores) and $1 \mathrm{~km}$ (in the peripheral areas). The neighborhood areas used in this analysis differ from the statistical NYKO4 areas. The original NYKO4 areas labeled with 0 (like 1200) include only the street area. To do a proper calculation for neighborhood areas the neighborhood borders were adjusted and they include part of 0 labelled NYKO4 (street area) plus the consecutive numbers (for example part of 1200 plus 1201 and 1202). The border of the neighborhood goes along axes of streets surrounding it.

Density as number of residents, jobs and residential and commercial floor space (FSI represents a rate between total floor space and neighborhood area) are available through the statistics. The network and Euclidean distances were calculated in meters with Network Analyst in ArcGIS. Network dataset was created with the street network and shortest distances were calculated from the centroid of the neighborhood to the city center of Karlstad (Stora Torget, translated as Big Square). Network Analyst calculates the network distance in meters and creates a shortest line from the origin to the destination which allows to calculate Euclidean distance. The AMPAK statistical package includes number of employed and number of residents in respect to job type. The income was calculated by multiplying the average salary per job type with number of jobs and employed residents per job type. The sum was then divided by the total number of jobs and employed residents to calculate the average salary as Neighborhood Gross Product (NGP).

\section{Typo-morphological study of Karlstad}

Karlstad is a small Swedish city with around 60000 inhabitants. It is a vibrant business hub of its region with over 40000 work places. The old core of Karlstad ('stenstad') is surrounded by 'cities with villas'. As many small Swedish cities, Karlstad grew rapidly in the second half of the 20th century. The expressway E-18, the main traffic artery, meanders to better adapt to the delta of Klarälv. Many of the neighborhoods developed with good access to E-18. Three 'modernist cities' ('funktionalistisk stad') surround the old core (with IDs 17, 53 and 36). These 'modernist cities' have typical community centers which have satellites on their own (residential areas, office parks, industrial zones and external shopping centers, etc.) around them. The map also shows that there are patches of urban areas which cannot be easily classified by the proposed typology (Figure 3). Generally, the proposed typology is applicable to classify large part of the city.

\section{Statistical analyses of neighborhood type}

ANOVA were conducted in SPSS to analyze different built environment factors and socioeconomic and demographic variables in the typical neighborhoods in Karlstad (Figure 4). The ANOVA tables supported by charts and descriptive statistics are presented and discussed in the following four subsections.

\section{Neighborhood type and density}

Table 2 shows the descriptive statistics for different density variables. The standard deviations are comparably small in respect 


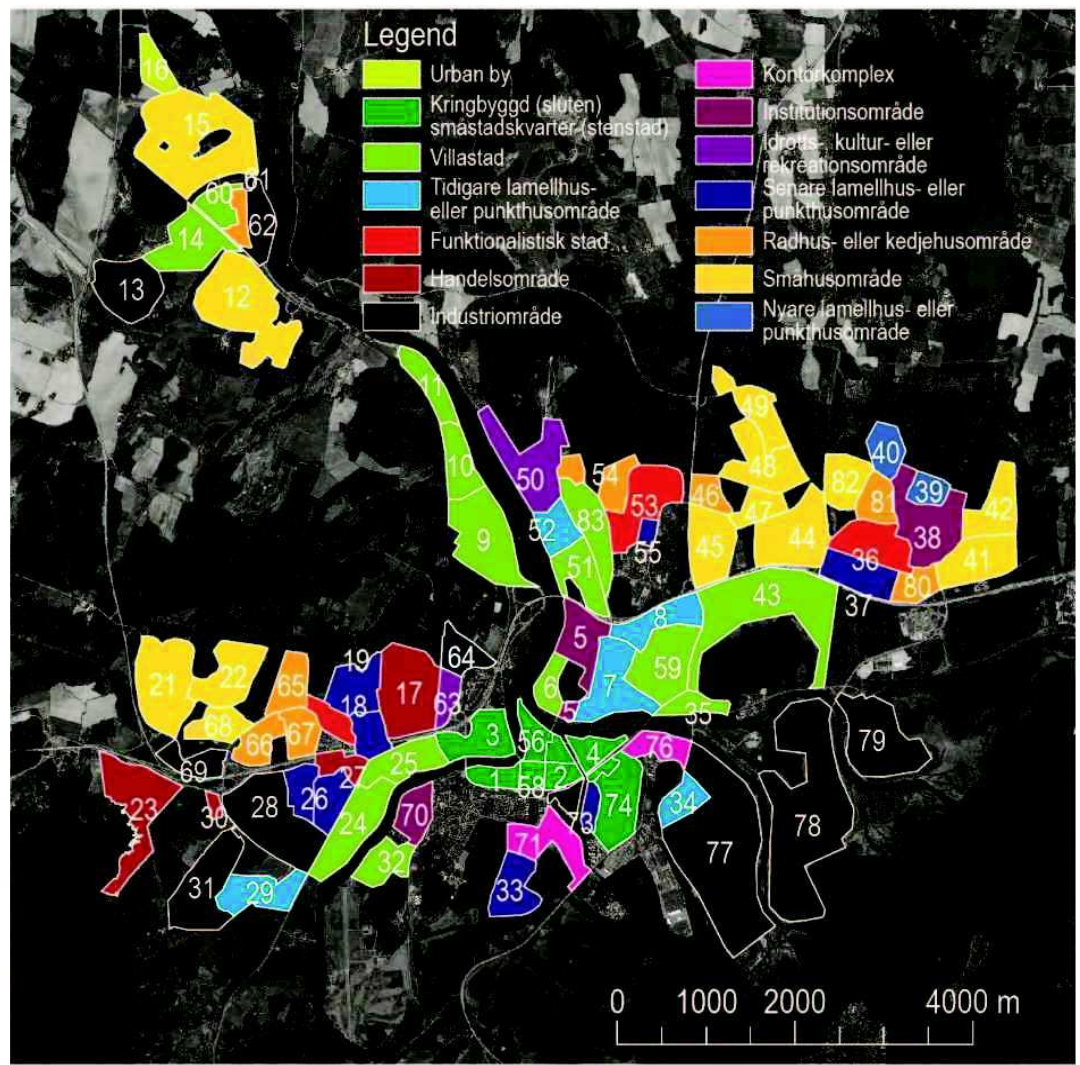

Figure 4.

Typo-morphological map of the neighborhoods in Karlstad

to the mean for the predominantly residential areas. The standard deviations are larger for commercial and industrial areas. This might be due to not well developed typology of commercial and industrial areas. The typomorphological classifications used (Engström et al. 1988; Rådberg 1988; Rådberg \& Friberg 1996; SBK, 1997; 2000) focus in greater detail on residential areas. The sample size is usually smaller for commercial or industrial neighborhood types (between 2 and 4), whereas slightly larger for residential (between 5 and 13). The sample size is small for valid statistical analyses.

Table 3 and 4 show the ANOVA table for population and built environment density. The one-way between subject ANOVA in SPSS revealed a statistical significant effect for residential $(\mathrm{F}(13,85)=13.7, \mathrm{p}<0.0005, \eta 2=$ $0.715)$, employment density $(\mathrm{F}(13,85)=7.204$, $\mathrm{p}<0.0005, \eta 2=0.569)$ and population (jobs and residents) density $(\mathrm{F}(13,85)=13.818, \mathrm{p}<$ $0.0005, \eta 2=0.717$ ). The conducted one-way between subject ANOVA for built environment density (FSIs) also shows statistical significant effect for residential FSI $(\mathrm{F}(13,85)=13.376$, $\mathrm{p}<0.0005, \eta 2=0.710)$, commercial FSI $(\mathrm{F}(13,85)=5.247, \mathrm{p}<0.0005, \eta 2=0.490)$ and FSI $(\mathrm{F}(13,85)=8.384, \mathrm{p}<0.0005, \eta 2=$ 0.606). The charts on Figure 5 illustrate the relationships jobs vs. residents, commercial vs. residential FSIs, and population vs. built density.

\section{Neighborhood type and location (distance from Karlstads's city center)}

The descriptive statistics for location are presented on Table 5. The standard deviations are often comparably small in respect to the mean. It is striking that the Euclidean amd network distances between the centroids of the 'modernist community centers' ('funktionalistisk stad') and the central square of Karlstad deviate very little. They are basically like satellites on a same circular path around the old core. 

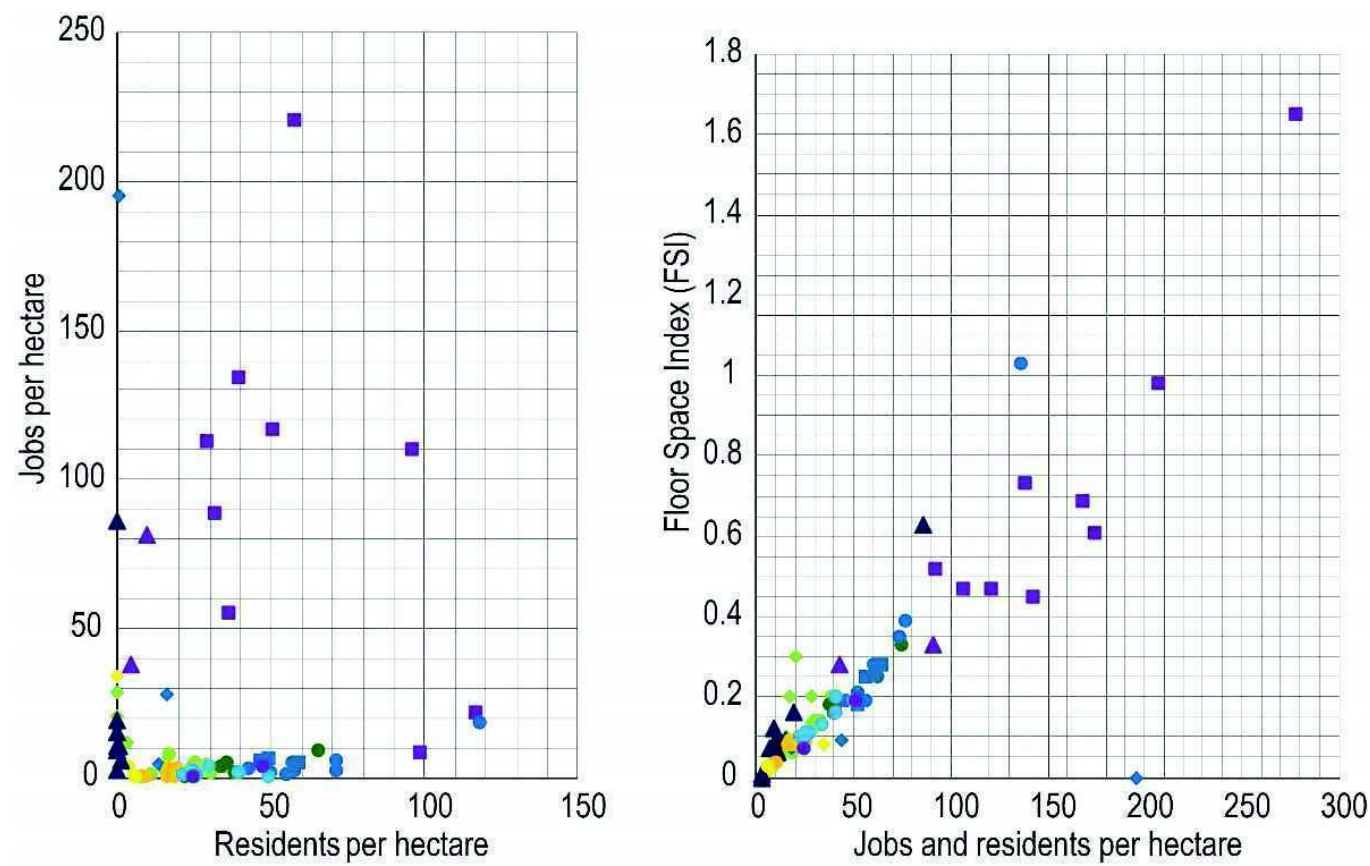

- Kringbyggd (sluten) småstadskvarter (stenstad)

- Villastad

- Tidigare lamellhus- eller punkthusområde

- Funktionalistisk stad

- Senare lamellhus- eller punkthusområde

- Institutionsområde

- Idrotts-, kultur- eller rekreationsområde

- Handelsområde

$\Delta$ Industriområde

$\Delta$ Kontorkomplex

- Småhusområde

- Radhus- eller kedjehusområde

Urban by

- Nyare lamellhus- eller punkthusområde

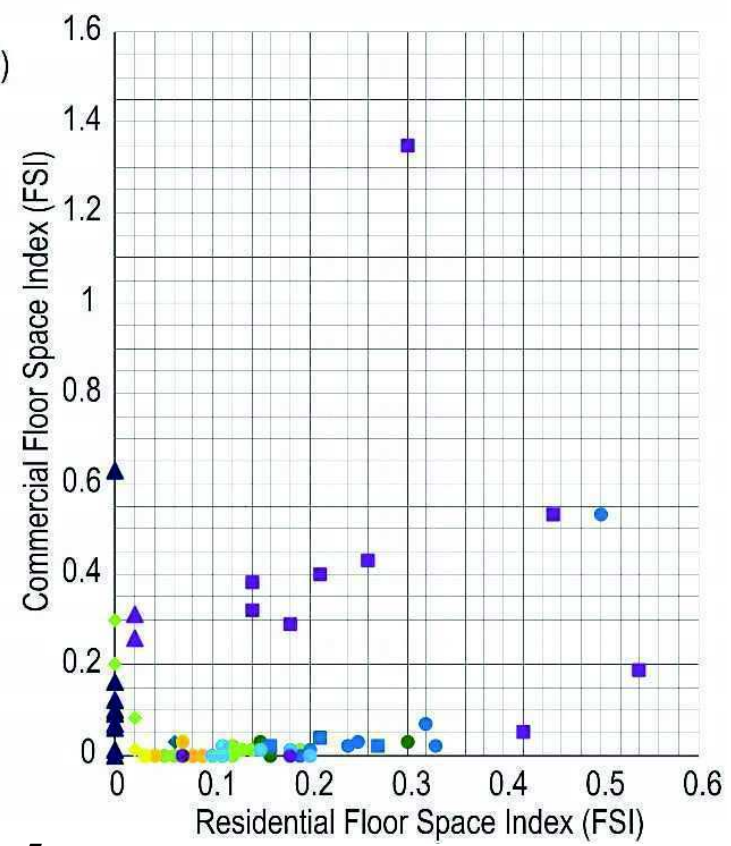

Figure 5.

Neighborhood type and density

Table 6 presents the ANOVA table for Euclidean and network distance to the center. The one-way between subject ANOVA in SPSS shows a statistical significant effect for Euclidean $(\mathrm{F}(13,85)=5.547, \mathrm{p}<0.0005, \eta 2$ $=0.504)$ and network distance to the center $(\mathrm{F}(13,85)=5.867, \mathrm{p}<0.0005, \eta 2=0.518)$. Figure 7 illustrates the directness relationship between Euclidean and network distance.

\section{Neighborhood type and income}

The descriptive statistics for income as average salary are presented on Table 7 . The standard deviations are often, especially for the residential neighborhood, comparably small in respect to the mean (roughly 1000 Swedish crowns which corresponds roughly to 100 Euros).

The ANOVA table for income as average 


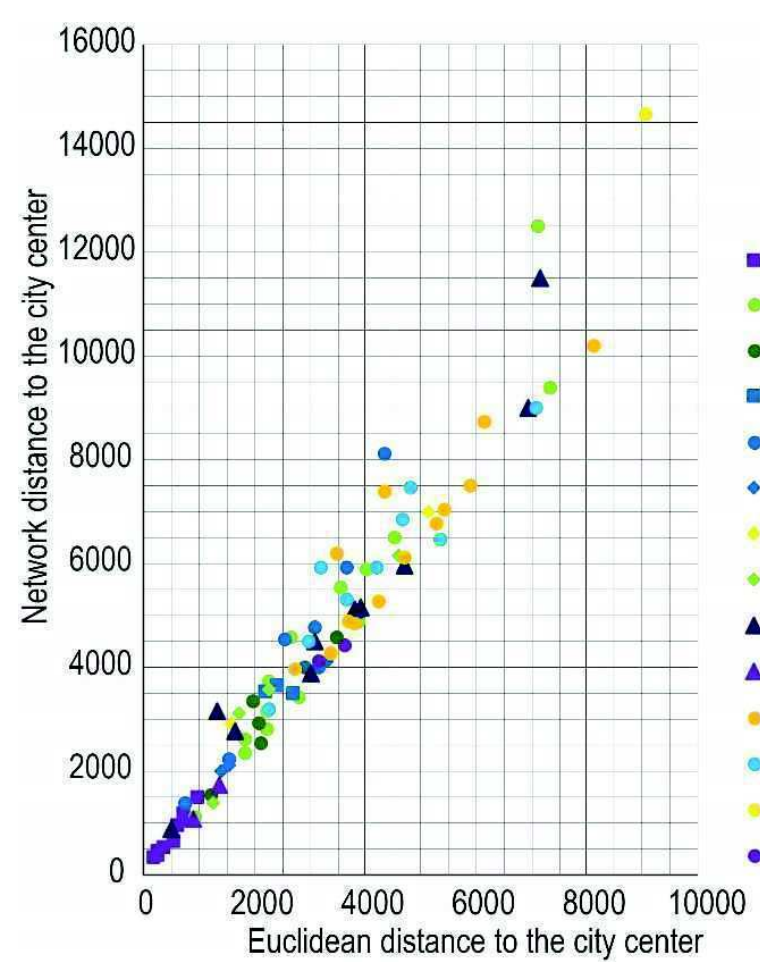

- Kringbyggd (sluten) småstadskvarter (stenstad)

- Villastad

- Tidigare lamellhus- eller punkthusområde

- Funktionalistisk stad

- Senare lamellhus- eller punkthusområde

- Institutionsområde

Idrotts-, kultur- eller rekreationsområde

- Handelsområde

^Industriområde

$\Delta$ Kontorkomplex

- Småhusområde

- Radhus- eller kedjehusområde

Urban by

-Nyare lamellhus- eller punkthusområde

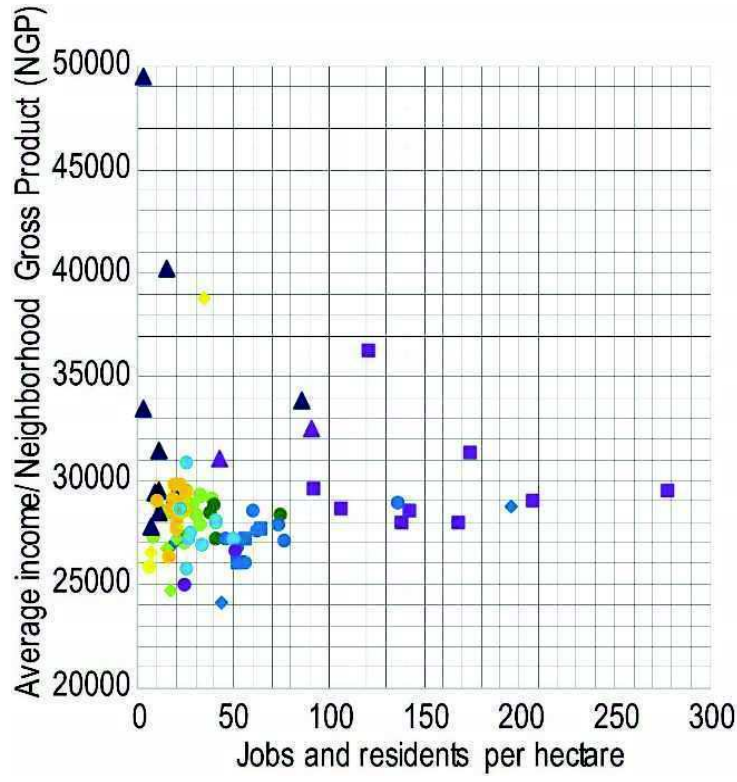

- Kringbyggd (sluten) småstadskvarter (stenstad)

- Villastad

- Tidigare lamellhus- eller punkthusområde

- Funktionalistisk stad

- Senare lamellhus- eller punkthusområde

- Institutionsområde

- Idrotts-, kultur- eller rekreationsområde

- Handelsområde

\Industriområde

$\Delta$ Kontorkomplex

Småhusområde

- Radhus- eller kedjehusområde

Urban by

- Nyare lamellhus- eller punkthusområde

Figures 6 and 7.

Neighborhood type and location (above). Neighborhood type and income as NGP (below)

salary per employed resident and job is presented on Table 8 The one-way between subject ANOVA in SPSS shows a statistical significant effect $(\mathrm{F}(13,85)=3.166, \mathrm{p}<0.0005$, $\eta 2=0.367)$, though slightly lower than for the other variables. Figure 7 shows the distribution of values by different neighborhood types on a scatter plot.

\section{Conclusion}

Even though the sample of neighborhoods from the city is rather small $(\mathrm{N}=85)$, the results show high explanation coefficients $(\eta 2>0.49)$ and statistical significance for all physical (urban form) parameters (Table 9). The explanation coefficients for income is 
lower $(\eta 2=0.367)$, but in a way it supports the hypothesis that neighborhood type is directly influenced by physical factors, and indirectly by socioeconomic and demographic. The low standard deviations (for residential neighborhoods and high for the other also support the hypothesis that typical homes attract social groups with similar income. The ANOVA method can be applied to analyze and compare means for different built environment and demographic variables. The measures of association in the ANOVA analysis show statistical significance. One city does not harness a large sample to execute a valid statistical analysis, but the method has potential both in urban modelling and typo-morphology, both to analyze and inform in planning (Batty, 2016; Wee, 2016) and to discuss future changes. Overall, methodology from the spatial analytical approach can be used to analyze studies from the typo-morphological tradition and vice versa.

\section{References}

Abarkan, A. (2009). The study of urban form in Sweden. Urban Morphology, 13(2), 121.

Abarkan, A. (2013). Typo-morfologi: Metoden och dess tillämpning på bebyggelsesmönster. The Nordic Journal of Architectural Research, 13 (1-2).

Batty, M. (1976) Urban Modelling: Algorithms, Calibrations, Predictions (Cambridge University Press, Cambridge)

Batty, M. (2005). Cities and Complexity: Understanding Cities with Cellular Automata, Agent-Based Models, and Fractals (MIT Press, Cambridge).

Batty, M (2016). "A science of cities Prologue to a science of planning", in Haselsberger, B. (ed.) Encounters in planning thought 16 autobiographical essays from key thinkers in spatial planning. New York: Routledge.

Birkhamshaw, A. J., \& Whitehand, J. W. R. (2012). Conzenian urban morphology and the character areas of planners and residents. Urban Design International, 17(1), 4-17.

Björk, C., Reppen, L. \& Kallstenius, P. (1983). Så byggdes husen 1880-1980: arkitektur, konstruktion och material i våra flerbostadshus under 100 år. Stockholm: Statens råd för byggnadsforskning.

Björk C., Kallstenius P.and Reppen L., (2003), Så byggdes husen 1880-2000, Stockholm: Forskningsrådet Formas

Björk C., Nordling L. and Reppen L., (2009), Så byggdes villan: svensk villarkitektur från 1890 till 2010, Stockholm: Forskningsrådet Formas

Bourdieu, P. (1985) The Social Space and the Genesis of Groups. Theory and Society, 14(6), 723-744.

Cataldi, G., Maffei, G. L., and Vaccaro, P. (2002) 'Saverio Muratori and the Italian school of planning typology', Urban Morphology 6(1), 3-14.

Cataldi, G. (2003) 'From Muratori to Caniggia: the origins and development of the Italian school of design typology', Urban Morphology, 7(1), 19-34.

Conzen, M. R. G. (1960). Alnwick, Northumberland: a study in town-plan analysis. Transactions and Papers (Institute of British Geographers), (27), iii-122.

Chadwick, G. F. (1971) A systems view of planning (Pergamon Press, Oxford).

Engström C.J, Lindqvist A., Lagbo E. och Landahl, G. 1988. Svensk tätort. Stockholm: Svenskakommunförbundet.

Engstrom C.J, och Legeby F. (2001). Scenariostudie om framtidsstaden. Göteborg: Chalmers tekniska högskola.

Engstrom C.J. (2008) "Kunskapsdriven näringsutveckling och stadsomvandling" i Cars, G., och Engström, C. J. (eds.). Stadsregioners utvecklingskraft-trender och nya perspektiv.

Franck, K.A. 1994. "Types are us”, i Franck, K.A. och Schneekloth, L.H. (eds.). Ordering space: types in architecture and design. New York: Van Nostrand Reinhold.

Hall, T. (2008). Where have all the gardens gone?. Australian Planner, 45(1), 30-37.

Hall, T. (2010). Goodbye to the backyard?the minimisation of private open space in the Australian outer-suburban estate. Urban Policy and Research, 28(4), 411-433.

Harris, B. (1965) 'New Tools for Planning', Journal of the American Institute of Planners 31(2), 90-95

Kropf, K. (2001). Conceptions of change in the 
built environment. Urban Morphology, 5(1), $29-46$.

Kropf, K. (2009). Aspects of urban form. Urban Morphology, 13(2), 105

Lynch, K. (1960). The image of the city. Cambridge, Massachusetts: M.I.T. Press.

Marshall, S. (2005). Urban pattern specification. London: Institute of Community Studies.

Marshall, S., \& Çalişkan, O. (2011). "A joint framework for urban morphology and design". Built Environment, 37(4), 409-426.

Moudon, A. V. (1997). Urban morphology as an emerging interdisciplinary field. Urban morphology, 1, 3-10.

Panerai, Philippe, Castex, Jean \& Depaule, Jean Charles (2004). Urban forms: the death and life of the urban block. Oxford: Architectural Press

Rex, J., \& Moore, R. S. (1969) Race, community and conflict: a study of Sparkbrook (Oxford University Press, London).

Rex, J. (1971) 'The concept of housing class and the sociology of race relations', Race \& Class 12(3), 293-301.

Rådberg, J. 1988. Doktrin och täthet i svenskt stadsbyggande 1875-1975. Stockholm: Statens råd för byggnadsforskning.

Rådberg, J. 2000. Attraktiva kvarterstyper: en undersökning av bebyggelse, befolkning och attraktivitet i Stockholm Söderort. Stockholm: Kungliga Tekniska högskolan.

Rådberg, J. och Friberg, A. 1996. Svenska stadstyper: historik, exempel, klassificering. Stockholm: Kungliga Tekniska högskolan.

Rådberg, J. och Johansson, R. 1997. Stadstyp och kvalitet. Stockholm: Kungliga Tekniska högskolan

Southworth, M., \& Owens, P. M. (1993). The evolving metropolis: studies of community, neighborhood, and street form at the urban edge. Journal of the American Planning Association, 59(3), 271-287.

Southworth, M., \& Ben-Joseph, E. (1997). Streets and the Shaping of Towns and Cities. New York: McGraw-Hill

Southworth, M. (2005). Reinventing main street: From mall to townscape mall. Journal of Urban Design, 10(2), 151-170.

Stead, D., \& Marshall, S. (2001). The relationships between urban form and travel patterns. An international review and evaluation. European Journal of Transport and Infrastructure Research, 1(2), 113-141.

Wee, 2016

SBK (Stockholms Stadsbyggnadskontoret). (1997). Stockholms byggnadsordning. Stockholm: SBK

SBK. (2000). ÖP99. Stockholm: SBK

SLL (Stockholms Läns Landsting). (2009). Tätare Stockholm. Stockholm: SLL.

Whitehand, J. W. (1987). The changing face of cities: a study of development cycles and urban form. Oxford: Basil Blackwell.

Whitehand, J. W. (2001) 'British urban morphology: the Conzenion tradition' Urban Morphology 5(2), 103-109. 


\section{Appendix}

\begin{tabular}{|c|c|c|c|c|c|c|}
\hline Neighborhood type & Period & Street layout & Building type & Land use & $\begin{array}{l}\text { Daily } \\
\text { activity }\end{array}$ & $\begin{array}{l}\text { Transportation } \\
\text { mode }\end{array}$ \\
\hline Urban by & Traditional & Linear & $\begin{array}{l}\text { Detached } \\
\text { buildings }\end{array}$ & $\begin{array}{l}\text { Agricultural/ } \\
\text { residential }\end{array}$ & $\begin{array}{l}\text { Non work } \\
\text { hours }\end{array}$ & $\begin{array}{l}\text { Walking/pri- } \\
\text { vate car }\end{array}$ \\
\hline Trästad & Traditional & $\begin{array}{l}\text { Interconnected } \\
\text { streets }\end{array}$ & Quadrangles & $\begin{array}{l}\text { Mixed/ } \\
\text { agricultural }\end{array}$ & Perpetual & Walking \\
\hline Stenstad & Traditional & $\begin{array}{l}\text { Interconnected } \\
\text { streets }\end{array}$ & $\begin{array}{l}\text { Enclosed } \\
\text { blocks }\end{array}$ & Mixed & Perpetual & Walking \\
\hline $\begin{array}{l}\text { Kringbyggd (sluten) } \\
\text { småstadskvarter (stenstad) }\end{array}$ & Industrial & $\begin{array}{l}\text { Interconnected } \\
\text { streets }\end{array}$ & $\begin{array}{l}\text { Enclosed } \\
\text { blocks }\end{array}$ & Mixed & Perpetual & Walking \\
\hline $\begin{array}{l}\text { Kringbyggd (sluten) } \\
\text { storstadkvarter (stenstad) }\end{array}$ & Industrial & $\begin{array}{l}\text { Interconnected } \\
\text { streets }\end{array}$ & $\begin{array}{l}\text { Enclosed } \\
\text { blocks }\end{array}$ & Mixed & Perpetual & Walking \\
\hline $\begin{array}{l}\text { Kringbyggd (sluten) } \\
\text { storstadsstorgårdskvarter }\end{array}$ & Industrial & $\begin{array}{l}\text { Interconnected } \\
\text { streets }\end{array}$ & $\begin{array}{l}\text { Enclosed } \\
\text { blocks }\end{array}$ & Mixed & Perpetual & Public transit \\
\hline Trädgårdsstad & Industrial & $\begin{array}{l}\text { Interconnected } \\
\text { streets }\end{array}$ & $\begin{array}{l}\text { Detached } \\
\text { buildings }\end{array}$ & Mixed & Perpetual & Public transit \\
\hline Villastad & Industrial & $\begin{array}{l}\text { Interconnected } \\
\text { streets }\end{array}$ & $\begin{array}{l}\text { Detached } \\
\text { buildings }\end{array}$ & Residential & $\begin{array}{l}\text { Non work } \\
\text { hours }\end{array}$ & Public transit \\
\hline $\begin{array}{l}\text { Tidigare lamellhus- eller } \\
\text { punkthusområde }\end{array}$ & $\begin{array}{l}\text { Early mod- } \\
\text { ernist }\end{array}$ & $\begin{array}{l}\text { Interconnected } \\
\text { streets /road } \\
\text { hierarchy }\end{array}$ & $\begin{array}{l}\text { Detached } \\
\text { buildings }\end{array}$ & Residential & $\begin{array}{l}\text { Non work } \\
\text { hours }\end{array}$ & Public transit \\
\hline Stenstad (moderniserad) & Modernist & Road hierarchy & Complexes & Mixed & Perpetual & Private car \\
\hline Funktionalistisk stad & Modernist & Road hierarchy & Mix & Mixed & Perpetual & Private car \\
\hline Centrum & Modernist & Road hierarchy & $\begin{array}{l}\text { Complexes } \\
\text { (big box) }\end{array}$ & $\begin{array}{l}\text { Retail and ser- } \\
\text { vices/ } \\
\text { community } \\
\text { services }\end{array}$ & Work hours & Private car \\
\hline Kontorkomplex & Modernist & Road hierarchy & Complexes & Business & Work hours & Private car \\
\hline Industriområde & Modernist & Road hierarchy & $\begin{array}{l}\text { Complexes } \\
\text { (big box) }\end{array}$ & Industry & Work hours & Private car \\
\hline Handelsområde & Modernist & Road hierarchy & $\begin{array}{l}\text { Complexes } \\
\text { (big box) }\end{array}$ & Retail & Work hours & Private car \\
\hline Institutionsområde & Modernist & Road hierarchy & Complexes & $\begin{array}{l}\text { Community } \\
\text { services }\end{array}$ & Work hours & Private car \\
\hline $\begin{array}{l}\text { Idrotts-, kultur- eller } \\
\text { rekreationsområde }\end{array}$ & Modernist & Road hierarchy & Complexes & $\begin{array}{l}\text { Assembly and } \\
\text { leisure }\end{array}$ & Events & Private car \\
\hline $\begin{array}{l}\text { Radhus- eller kedjehusom- } \\
\text { råde }\end{array}$ & Modernist & Road hierarchy & $\begin{array}{l}\text { Buildings in } \\
\text { rows }\end{array}$ & Residential & $\begin{array}{l}\text { Non work } \\
\text { hours }\end{array}$ & Private car \\
\hline Småhusområde & Modernist & Road hierarchy & $\begin{array}{l}\text { Detached } \\
\text { buildings }\end{array}$ & Residential & $\begin{array}{l}\text { Non work } \\
\text { hours }\end{array}$ & Private car \\
\hline Fritidshusområde & Modernist & Road hierarchy & $\begin{array}{l}\text { Detached } \\
\text { buildings }\end{array}$ & Recreational & & Private car \\
\hline $\begin{array}{l}\text { Senare lamellhus- eller } \\
\text { punkthusområde }\end{array}$ & Modernist & Road hierarchy & $\begin{array}{l}\text { Detached } \\
\text { buildings }\end{array}$ & Residential & $\begin{array}{l}\text { Non work } \\
\text { hours }\end{array}$ & Private car \\
\hline $\begin{array}{l}\text { Nyare lamellhus- eller } \\
\text { punkthusområde }\end{array}$ & $\begin{array}{l}\text { Late mod- } \\
\text { ernist }\end{array}$ & Road hierarchy & $\begin{array}{l}\text { Detached } \\
\text { buildings /com- } \\
\text { plexes }\end{array}$ & Residential & $\begin{array}{l}\text { Non work } \\
\text { hours }\end{array}$ & Private car \\
\hline $\begin{array}{l}\text { Kvasi-stadskvarter (sten- } \\
\text { stad) }\end{array}$ & Postmodernist & $\begin{array}{l}\text { Quasi intercon- } \\
\text { nected streets }\end{array}$ & $\begin{array}{l}\text { Quasi enclosed } \\
\text { blocks }\end{array}$ & Mixed & Perpetual & Multimodal \\
\hline
\end{tabular}

Table 1:

Swedish neighborhood types and their morphological characteristics (inspired by Whitehand, 2001). 


\begin{tabular}{|c|c|c|c|c|c|c|c|c|c|c|c|c|c|}
\hline \multirow{2}{*}{$\begin{array}{l}\text { Neighborhood } \\
\text { type }\end{array}$} & \multicolumn{2}{|c|}{$\begin{array}{l}\text { Dependent } \\
\text { Variable: } \\
\text { Residents per } \\
\text { hectare }\end{array}$} & \multicolumn{2}{|c|}{$\begin{array}{l}\text { Dependent } \\
\text { Variable: Jobs } \\
\text { per hectare }\end{array}$} & \multicolumn{2}{|c|}{$\begin{array}{l}\text { Dependent } \\
\text { Variable: Resi- } \\
\text { dents and jobs } \\
\text { per hectare }\end{array}$} & \multicolumn{2}{|c|}{$\begin{array}{l}\text { Dependent } \\
\text { Variable: Res- } \\
\text { idential FSI }\end{array}$} & \multicolumn{2}{|c|}{$\begin{array}{l}\text { Dependent } \\
\text { Variable: } \\
\text { Commercial } \\
\text { FSI }\end{array}$} & \multicolumn{3}{|c|}{$\begin{array}{l}\text { Dependent } \\
\text { Variable: Floor } \\
\text { Space Index } \\
\text { (FSI) }\end{array}$} \\
\hline & 51.50 & 6.56 & 5.77 & 0.78 & 57.27 & 5.88 & 0.213 & 0.055 & 0.027 & 0.012 & 0.237 & 0.051 & 3 \\
\hline $\begin{array}{l}\text { Funktionalistisk } \\
\text { stad }\end{array}$ & 0.83 & 1.65 & 19.25 & 6.85 & 20.08 & 5.80 & 0.005 & 0.010 & 0.195 & 0.090 & 0.200 & 0.082 & 4 \\
\hline Handelsområde & 1.75 & 2.47 & 18.90 & 21.64 & 20.65 & 19.16 & 0.010 & 0.014 & 0.045 & 0.049 & 0.050 & 0.042 & 2 \\
\hline $\begin{array}{l}\text { Idrotts-, kultur- } \\
\text { eller rekreation- } \\
\text { sområde }\end{array}$ & 0.19 & 0.41 & 17.10 & 24.73 & 17.30 & 24.64 & 0.000 & 0.000 & 0.133 & 0.181 & 0.133 & 0.181 & 10 \\
\hline Industriområde & 9.80 & 8.47 & 75.67 & 104.10 & 85.47 & 95.89 & 0.043 & 0.038 & 0.010 & 0.017 & 0.053 & 0.047 & 3 \\
\hline $\begin{array}{l}\text { Institutionsom- } \\
\text { råde }\end{array}$ & 7.15 & 3.61 & 59.75 & 30.90 & 66.95 & 34.44 & 0.020 & 0.000 & 0.285 & 0.035 & 0.305 & 0.035 & 2 \\
\hline Kontorkomplex & 61.70 & 33.19 & 96.54 & 64.02 & 158.24 & 57.16 & 0.293 & 0.146 & 0.438 & 0.370 & 0.730 & 0.384 & 9 \\
\hline $\begin{array}{l}\text { Kringbyggd } \\
\text { (sluten) småstad- } \\
\text { skvarter (sten- } \\
\text { stad) }\end{array}$ & 36.00 & 16.12 & 1.85 & 2.33 & 37.80 & 18.53 & 0.125 & 0.078 & 0.000 & 0.000 & 0.130 & 0.085 & 2 \\
\hline $\begin{array}{l}\text { Nyare lamellhus- } \\
\text { eller punkthu- } \\
\text { sområde }\end{array}$ & 30.80 & 9.59 & 1.52 & 1.19 & 32.32 & 9.53 & 0.130 & 0.037 & 0.004 & 0.007 & 0.134 & 0.039 & 9 \\
\hline $\begin{array}{l}\text { Radhus- eller } \\
\text { kedjehusområde }\end{array}$ & 65.29 & 23.31 & 4.95 & 5.62 & 70.23 & 28.55 & 0.276 & 0.106 & 0.086 & 0.181 & 0.361 & 0.280 & 8 \\
\hline $\begin{array}{l}\text { Senare lamell- } \\
\text { hus- eller punk- } \\
\text { thusområde }\end{array}$ & 18.25 & 3.80 & 1.48 & 0.85 & 19.72 & 4.02 & 0.082 & 0.015 & 0.002 & 0.008 & 0.084 & 0.014 & 13 \\
\hline Småhusområde & 38.88 & 16.19 & 4.04 & 3.35 & 42.90 & 19.28 & 0.172 & 0.077 & 0.014 & 0.015 & 0.190 & 0.085 & 5 \\
\hline $\begin{array}{l}\text { Tidigare lamell- } \\
\text { hus- eller punk- } \\
\text { thusområde }\end{array}$ & 5.70 & & 0.10 & & 5.80 & & 0.030 & & 0.000 & & 0.030 & & 1 \\
\hline Urban by & 21.97 & 8.03 & 2.93 & 1.93 & 24.92 & 8.71 & 0.101 & 0.042 & 0.005 & 0.007 & 0.105 & 0.046 & 14 \\
\hline Villastad & 27.98 & 25.80 & 19.48 & 41.33 & 47.47 & 50.69 & 0.123 & 0.116 & 0.091 & 0.196 & 0.214 & 0.254 & 85 \\
\hline Total & 27.98 & 25.80 & 19.48 & 41.33 & 47.47 & 50.69 & 0.123 & 0.116 & 0.091 & 0.196 & 0.214 & 0.254 & 85 \\
\hline
\end{tabular}

Table 2:

Descriptive statistics for density variables 
Dependent Variable: Residents per hectare

\begin{tabular}{|l|llllll|}
\hline \multirow{2}{*}{$\begin{array}{l}\text { Source } \\
\text { Corrected Model }\end{array}$} & $\begin{array}{l}\text { Type III Sum of } \\
\text { Squares }\end{array}$ & df & Mean Square & F & Sig. & $\begin{array}{l}\text { Partial Eta } \\
\text { Squared }\end{array}$ \\
\cline { 2 - 7 } Intercept & $39961.346^{\mathrm{a}}$ & 13 & 3073.950 & 13.700 & 0.000 & 0.715 \\
Neighborhood type & 29049.974 & 1 & 29049.974 & 129.468 & 0.000 & 0.646 \\
Error & 39961.346 & 13 & 3073.950 & 13.700 & 0.000 & 0.715 \\
Total & 15931.004 & 71 & 224.380 & & & \\
Corrected Total & 122459.570 & 85 & & & & \\
\cline { 2 - 8 }
\end{tabular}

a. R Squared $=0.715$ (Adjusted R Squared $=0.663$ )

Dependent Variable: Jobs per hectare

\begin{tabular}{|c|c|c|c|c|c|c|}
\hline Source & $\begin{array}{l}\text { Type III Sum of } \\
\text { Squares }\end{array}$ & df & Mean Square & $\mathrm{F}$ & Sig. & $\begin{array}{l}\text { Partial Eta } \\
\text { Squared }\end{array}$ \\
\hline Corrected Model & $81615.449^{\mathrm{a}}$ & 13 & 6278.111 & 7.204 & 0.000 & 0.569 \\
\hline Intercept & 22791.726 & 1 & 22791.726 & 26.154 & 0.000 & 0.269 \\
\hline Neighborhood type & 81615.449 & 13 & 6278.111 & 7.204 & 0.000 & 0.569 \\
\hline Error & 61871.435 & 71 & 871.429 & & & \\
\hline Total & 175749.660 & 85 & & & & \\
\hline Corrected Total & 143486.884 & 84 & & & & \\
\hline \multicolumn{7}{|c|}{ a. R Squared $=0.569($ Adjusted R Squared $=0.490)$} \\
\hline \multicolumn{7}{|c|}{ Dependent Variable: Jobs and residents per hectare } \\
\hline Source & $\begin{array}{l}\text { Type III Sum of } \\
\text { Squares }\end{array}$ & df & Mean Square & $\mathrm{F}$ & Sig. & $\begin{array}{l}\text { Partial Eta } \\
\text { Squared }\end{array}$ \\
\hline Corrected Model & $154721.734^{\mathrm{a}}$ & 13 & 11901.672 & 13.818 & 0.000 & 0.717 \\
\hline Intercept & 103301.526 & 1 & 103301.526 & 119.932 & 0.000 & 0.628 \\
\hline Neighborhood type & 154721.734 & 13 & 11901.672 & 13.818 & 0.000 & 0.717 \\
\hline Error & 61154.610 & 71 & 861.333 & & & \\
\hline Total & 407401.180 & 85 & & & & \\
\hline Corrected Total & 215876.344 & 84 & & & & \\
\hline
\end{tabular}

Table 3:

ANOVA table for population density 
Dependent Variable: Residential FSI

\begin{tabular}{|c|c|c|c|c|c|c|}
\hline Source & $\begin{array}{l}\text { Type III Sum of } \\
\text { Squares }\end{array}$ & df & $\begin{array}{l}\text { Mean } \\
\text { Square }\end{array}$ & $\mathrm{F}$ & Sig. & $\begin{array}{l}\text { Partial Eta } \\
\text { Squared }\end{array}$ \\
\hline Corrected Model & $.796^{\mathrm{a}}$ & 13 & 0.061 & 13.376 & 0.000 & 0.710 \\
\hline Intercept & .535 & 1 & 0.535 & 116.849 & 0.000 & 0.622 \\
\hline Neighborhood type & .796 & 13 & 0.061 & 13.376 & 0.000 & 0.710 \\
\hline Error & .325 & 71 & 0.005 & & & \\
\hline Total & 2.416 & 85 & & & & \\
\hline Corrected Total & 1.121 & 84 & & & & \\
\hline
\end{tabular}

a. R Squared $=0.710$ (Adjusted R Squared $=0.657)$

Dependent Variable: Commercial FSI

\begin{tabular}{|lllllll|}
\hline \multirow{2}{*}{$\begin{array}{l}\text { Source } \\
\text { Corrected Model }\end{array}$} & $\begin{array}{l}\text { Type III Sum of } \\
\text { Squares }\end{array}$ & $\begin{array}{l}\text { df } \\
\text { Intercept }\end{array}$ & $\begin{array}{l}\text { Mean } \\
\text { Square }\end{array}$ & F & Sig. & $\begin{array}{l}\text { Partial Eta } \\
\text { Squared }\end{array}$ \\
Neighborhood type & .368 & 13 & 0.122 & 5.247 & 0.000 & 0.490 \\
Error & 1.583 & 1 & 0.368 & 15.844 & 0.000 & 0.182 \\
Total & 1.648 & 13 & 0.122 & 5.247 & 0.000 & 0.490 \\
Corrected Total & 3.931 & 71 & 0.023 & & & \\
& 3.230 & 85 & & & & \\
\hline
\end{tabular}

a. R Squared $=0.490$ (Adjusted R Squared $=0.397)$

Dependent Variable: Floor Space Index (FSI)

\begin{tabular}{|c|c|c|c|c|c|c|}
\hline Source & $\begin{array}{l}\text { Type III Sum of } \\
\text { Squares }\end{array}$ & df & $\begin{array}{l}\text { Mean } \\
\text { Square }\end{array}$ & $\mathrm{F}$ & Sig. & $\begin{array}{l}\text { Partial Eta } \\
\text { Squared }\end{array}$ \\
\hline Corrected Model & $3.280^{\mathrm{a}}$ & 13 & 0.252 & 8.384 & 0.000 & 0.606 \\
\hline Intercept & 1.786 & 1 & 1.786 & 59.338 & 0.000 & 0.455 \\
\hline Neighborhood type & 3.280 & 13 & 0.252 & 8.384 & 0.000 & 0.606 \\
\hline Error & 2.137 & 71 & 0.030 & & & \\
\hline Total & 9.305 & 85 & & & & \\
\hline Corrected Total & 5.416 & 84 & & & & \\
\hline
\end{tabular}

Table 4:

ANOVA table for built density or Floor Space Indexes (FSI) 


\begin{tabular}{|l|l|l|l|l|l|l|}
\hline & \multicolumn{2}{l|}{$\begin{array}{l}\text { Dependent Vari- } \\
\text { able: Euclidean dis- } \\
\text { tance to Center (m) }\end{array}$} & $\begin{array}{l}\text { Dependent Variable: } \\
\text { Network Distance to } \\
\text { Center (m) }\end{array}$ & \\
\hline Neighborhood type & Mean & $\begin{array}{l}\text { Std. } \\
\text { Dev. }\end{array}$ & Mean & Std. Dev. & N \\
\hline Funktionalistisk stad & 2433 & 249 & 3555 & 76 & 3 \\
\hline Handelsområde & 2453 & 1491 & 3533 & 1980 & 4 \\
\hline Idrotts-, kultur- eller rekreationsområde & 3354 & 2542 & 4947 & 2859 & 2 \\
\hline Industriområde & 3605 & 2221 & 5178 & 3084 & 10 \\
\hline Institutionsområde & 2077 & 1062 & 2728 & 1194 & 3 \\
\hline Kontorkomplex & 1119 & 321 & 1403 & 469 & 2 \\
\hline Kringbyggd (sluten) småstadskvarter (stenstad) & 506 & 277 & 768 & 410 & 9 \\
\hline Nyare lamellhus- eller punkthusområde & 3380 & 334 & 4252 & 223 & 2 \\
\hline Radhus- eller kedjehusområde & 4245 & 1451 & 6053 & 1687 & 9 \\
\hline Senare lamellhus- eller punkthusområde & 2749 & 1148 & 4355 & 2080 & 8 \\
\hline Småhusområde & 4717 & 1450 & 6379 & 1803 & 13 \\
\hline Tidigare lamellhus- eller punkthusområde & 2173 & 809 & 2977 & 1117 & 5 \\
\hline Urban by & 9046 & & 14653 & & 1 \\
\hline Villastad & 3365 & 1908 & 4877 & 3022 & 14 \\
\hline Total & 3155 & 1972 & 4505 & 2836 & 85 \\
\hline
\end{tabular}

Table 5:

Descriptive statistics for location variables

Dependent Variable: Euclidean distance to Center (m)

\begin{tabular}{|c|c|c|c|c|c|c|}
\hline Source & $\begin{array}{l}\text { Type III Sum of } \\
\text { Squares }\end{array}$ & df & Mean Square & $\mathrm{F}$ & Sig. & Partial Eta Squared \\
\hline Corrected Model & $164545818.264^{\mathrm{a}}$ & 13 & 12657370.636 & 5.547 & 0.000 & 0.504 \\
\hline Intercept & 485469731.083 & 1 & 485469731.083 & 212.764 & 0.000 & 0.750 \\
\hline Neighborhood type & 164545818.264 & 13 & 12657370.636 & 5.547 & 0.000 & 0.504 \\
\hline Error & 162002736.559 & 71 & 2281728.684 & & & \\
\hline Total & 1172703781.000 & 85 & & & & \\
\hline Corrected Total & 326548554.824 & 84 & & & & \\
\hline \multicolumn{7}{|c|}{ a. $\mathrm{R}$ Squared $=0.504($ Adjusted R Squared $=0.413)$} \\
\hline \multicolumn{7}{|c|}{ Dependent Variable: Network Distance to Center (m) } \\
\hline Source & $\begin{array}{l}\text { Type III Sum of } \\
\text { Squares }\end{array}$ & df & Mean Square & $\mathrm{F}$ & Sig. & Partial Eta Squared \\
\hline Corrected Model & $349926523.751^{\mathrm{a}}$ & 13 & 26917424.904 & 5.867 & 0.000 & 0.518 \\
\hline Intercept & 1023385830.532 & 1 & 1023385830.532 & 223.052 & 0.000 & 0.759 \\
\hline Neighborhood type & 349926523.751 & 13 & 26917424.904 & 5.867 & 0.000 & 0.518 \\
\hline Error & 325754973.826 & 71 & 4588098.223 & & & \\
\hline Total & 2400857734.000 & 85 & & & & \\
\hline Corrected Total & 675681497.576 & 84 & & & & \\
\hline
\end{tabular}

Table 6:

ANOVA table for location (distance from Karlstads's city center) 


\begin{tabular}{|l|l|l|l|}
\hline & \multicolumn{2}{|l|}{$\begin{array}{l}\text { Dependent Variable: Average salary } \\
\text { (employed residents and jobs) }\end{array}$} & \\
\hline Neighborhood type & Mean & Std. Dev. & $\mathrm{N}$ \\
\hline Funktionalistisk stad & 26986 & 827 & 3 \\
Handelsområde & 26822 & 1655 & 4 \\
Idrotts-, kultur- eller rekreationsområde & 32684 & 8651 & 10 \\
Industriområde & 33309 & 6788 & 3 \\
Institutionsområde & 26552 & 2325 & 2 \\
Kontorkomplex & 31812 & 1037 & 9 \\
Kringbyggd (sluten) småstadskvarter (stenstad) & 29882 & 2599 & 2 \\
Nyare lamellhus- eller punkthusområde & 25793 & 1153 & 9 \\
Radhus- eller kedjehusområde & 27792 & 1411 & 8 \\
Senare lamellhus- eller punkthusområde & 27531 & 924 & 13 \\
Småhusområde & 28751 & 991 & 5 \\
Tidigare lamellhus- eller punkthusområde & 28019 & 728 & 1 \\
Urban by & 25812 & & 14 \\
Villastad & 28607 & 758 & 85 \\
\hline Total & 28953 & 3386 & \\
\hline
\end{tabular}

Table 7: Descriptive statistics of income

Dependent Variable: Average salary (employed residents and jobs)

\begin{tabular}{|c|c|c|c|c|c|c|}
\hline Source & Type III Sum of Squares & $\mathrm{df}$ & Mean Square & $\mathrm{F}$ & Sig. & $\begin{array}{l}\text { Partial Eta } \\
\text { Squared }\end{array}$ \\
\hline Corrected Model & $353425310.159^{\mathrm{a}}$ & 13 & 27186562.320 & 3.166 & 0.000 & 0.367 \\
\hline Intercept & 38051118840.251 & 1 & 38051118840.251 & 4431.634 & 0.000 & 0.984 \\
\hline Neighborhood type & 353425310.159 & 13 & 27186562.320 & 3.166 & 0.000 & 0.367 \\
\hline Error & 609623752.852 & 71 & 8586250.040 & & & \\
\hline Total & 72218727273.000 & 85 & & & & \\
\hline Corrected Total & 963049063.012 & 84 & & & & \\
\hline
\end{tabular}

Table 8: ANOVA table for income or Neighborhood Gross Product (NGP)

\begin{tabular}{|l|ll|}
\hline & Eta & Eta Squared \\
\hline Residents per hectare * Neighborhood type & 0.846 & 0.715 \\
Jobs per hectare * Neighborhood type & 0.754 & 0.569 \\
Jobs and residents per hectare * Neighborhood type & 0.847 & 0.717 \\
Residential FSI * Neighborhood type & 0.843 & 0.710 \\
Commercial FSI * Neighborhood type & 0.700 & 0.490 \\
FSI (Floor Space Index) * Neighborhood type & 0.778 & 0.606 \\
Euclidean Distance to Center (m)* Neighborhood type & 0.710 & 0.504 \\
Network Distance to Center (m) * Neighborhood type & 0.720 & 0.518 \\
Income average (employed residents and jobs) * Neighborhood type & 0.606 & 0.367 \\
\hline
\end{tabular}

Table 9: Measure of association of different variable and neighborhood type 